with a form of application for membership to each police surgeon whose name I have been able to find in the Constabulary Almanack. As, however, this does not contain a complete list, and as I am anxious to secure the membership of every police surgeon willing to join, I will send a copy to any who will forward to me his name and address.

I am, Sirs, yours faithfully,

FRED. W. LOWNDES, Honorary Secretary.

40, Knight-street, Liverpool, March 5th, 1903.

\section{THE CULTIVATION OF ANAEROBIC BACTERIA.}

To the Eiditors of THE LANCET.

SIRs,-Will you permit me to thank Dr. Klein for drawing my attention to his method of anaerobic plate culture as set forth in the medical officer's report for 1897-98. I am quite familiar with this method, as also with those of Gabritschewsky, Botkin, Hammerl, and other investigators who have worked at this subject. But in my hands these methods have not given uniformly satisfactory results, as, for instance, in the plate culture of such a strictly anaerobic microorganism as bacillus tetani.

Dr. Klein's method and mine are the same in principle but in apparatus they differ. I use a chamber having a very small air space provided with most efficient seal, whereby the vacuum created by the absorption of oxygen by the pyrogallic solution is maintained. In apparatus of the bell-glass pattern having a large air space $I$ have found that this is not always the case.

\section{I am, Sirs, yours faithfully,}

\section{H. S. FremLin.}

Government Lymph Laboratories, Chelsea Bridge, S.W., March 9th, 1903.'

\section{A DISCLAIMER.}

To the Editors of THE LANCET.

SIRs,-The report of an interview which appeared in the Daily Telegraph of March 3rd was published entirely without my authority or knowledge. I was quite unaware that the gentleman who engaged me in casual conversation in the office of the secretary of the hospital was a reporter.

I am, Sirs, yours faithfully,

Cavendish-square, W., March 9th, $1903 . \quad$ DUNDAS Grant.

\section{NOTES FROM INDIA.}

\section{(From OUR SPECIAL OORRESPONDRHT.)}

The Indisoriminate Sale of Cocaine in India.-Paralytic Affections among Men and Cattle in the Central Provinces. -The Cremation Society of Bengal.-The Plague Epidemic.-Reorganisation of the Health Department in Bombay.

THE Bombay High Court in a test case instituted at the instance of the Government of Bombay has held that cocaine is not an intoxicating drug within the meaning of the Excise Act. The effect of this ruling will apparently be that no licence such as has been insisted on by the Governments of Bengal and Bombay will be necessary for the sale of cocaine and that the law as it now stands is powerless to check the cocaine habit which, as I have previously reported, is spreading rapidly in many parts of India.

In consequence of the spread of a paralytic affection attacking human beings as well as cattle in parts of the Central Provinces an official inquiry is to be held. The complaint is due, it is believed, to the eating of certain classes of dhal, more particularly that known as kasari dhal, or latri. As the botanical name for this is lathyrus sativus the complaint will probably turn out to be a long-recognised one. The natives recognise its poisonous properties in both themselves and their animals but partake of it on account of its cheapness. Horses and bullocks lose control over the hind limbs, becoming paralysed. This grain is also said to produce dyspnoea and roaring in horses when put to work. Many years ago a widespread occurrence of paralysis in Sindh, after a season of extensive inundations in which kasari was grown on an exceptionally large scale, drew attention to it, and in the Azanzarh district, where paralysis is common, kasari forms an important article of diet.
The Cremation Society of Bengal, which now numbers nearly 100 members, is being registered under the Companies Act and hopes to obtain the control and management of the crematorium which the corporation proposes to erect.

The plague mortality continues to increase. Last week 25,870 deaths were reported throughout India, against 24,500 in the previous seven days and 15,165 in the corresponding week of last year. The Bombay Presidency returns 11,922 deaths, the Bengal Presidency 2817, and the Madras Presidency 592. Then we have the Punjab with 3735 deaths, the Central Provinces 206, the United Provinces 2599, the Mysore State 694, the Hyderabad State 932, and Berar 462. Bombay city reported 612 deaths from plague alone, Calcutta 142, Poona 849, and Karachi 33. When it is borne in mind that Poona contains only a little over 100,000 inhabitants the frightful mortality going on there will be recognised. Dr. Shave, one of the plague medical officers now at Sholapur, has been selected for appointment to the Indian Medical Service.

The health department of the Bombay municipality has been rearranged. Bombay is now divided into three divisions, each under the charge of a health officer. For purposes of registration the city has been divided into ten registration districts, in each of which there is a municipal dispensary. At each office there are a qualified native medical man and three hospital assistants who inquire into the cause of every death, investigate cases of infectious disease, and take action for removal to hospital. They also treat cases of sickness at the homes of the people in poor and urgent cases. A nurse who is a qualified midwife is attached to each district. Dr. J. A. Turner is the executive health officer and Dr. C. H. Cayley, Mr. W. Venis, and Dr. Sorab C. Hormusji are the divisional health officers.

Feb. 12th.

THE

ORGANISATION OF THE PROFESSION. (From oUR SPECIAL CoMmissioner.)

The Situation at Cardiff.--The South Wales Colliery Surgeons and the Poundage Pystem; the Satisfactory Payments obtained. - The Question of Concentration or of subdivision in Medical Practice.

THOUGH, as recently described, a notable effort has been successfully made to organise the profession at Swansea it must be admitted that, taking South Wales as a whole, but little has been done. The only other organisation brought to my notice was the East Glamorgan and Monmouthshire Colliery Surgeons' Medico-Ethical Society. At Cardiff, for instance, which is the most important town in South Wales, there is no medical union and this notwithstanding the presence of Mr. T. Garrett Horder who has made praiseworthy efforts in regard to the question of hospital abuse. Nevertheless, there seems to be a total absence of public spirit among the members of the profession at Cardiff. Some of the practitioners appear to fear having to subscribe to yet another institution and they complain that there are already so many calls made upon them. Nor is there any indication that they have realised that under its new constitution the British Medical Association, which is to meet so near to them this year, should be able to take economic questions in hand. It is doubtful if anyone has prepared any sort of statement or proposal or has fully grasped the leading potentialities of the new conditions and methods of organisation. On the other hand, there is this excuse-namely, that the rate of payment for contract work at Cardiff' is higher than it was at Swansea. The members of clubs for the most part pay $1 d$. per week and these are not family clubs. It will be remembered that at Swansea the average pay was $1 \frac{1}{2} d$. per week, or $6 s .6 d$. per annum, for family clubs. Such family clubs as exist at Cardiff pay, I am told, from $10 s$. to 13s. per year per family. Nevertheless, the dockers' medical aid organisation only pays $8 s$. $8 d$. per family; however, this latter and smaller figure is not lower than the terms accepted at Swansea. But, as one of the local practitioners explained, it is not so much the amount the members pay as the habits that prevail among them. In some societies or clubs the members may be impressed with the very just idea that as they pay so little they should only seek the advice of their medical officer when there is really need of 